\title{
The Roles of Supervisory Support Behaviors and Environmental Policy in Employee "Eco-initiatives" at Manufacturing Companies in Vietnam
}

\author{
NHÂM PHONG TUÂN \\ University of Economics and Business, Vietnam National University - tuannp@vnu.edu.vn \\ TAKAHASHI YOSHI \\ Hiroshima University (Japan)
}

NGUYẼ̃N THI TUYẾT MAI

Hiroshima University (Japan) - maichoe@gmail.com

\begin{abstract}
ARTICLE INFO
ABSTRACT

Article history:

Received:

Dec. 292013

Environmental issues are taking more attentions from many countries in the world and have forced proactive companies to adopt Received in revised form May 282014

Accepted: environmental policy and encourage supervisory support behaviors in an aim to increase employee willingness to promote ecoinitiatives. The study assessed environmental policy and supervisory June 302014 support behaviors as creating an impetus for environmental actions in companies, leading to environmentally proactive firms sending encourgamental signals to employees. Data of 212 mid- and lowlevel employees was collected from questionnaire survey at three companies located in Hà Nội and Đà Nẵng City in Vietnam during January 2013. By using likelihood ratio tests and logistic regression analyses, the results supported both two hypotheses: Environmental

Keywords:

supervisory support behaviors; employee ecoinitiatives; manufacturing policies will influence on employee willingness to promote ecoinitiatives; Supervisory support behaviors will influence on employee willingness to promote eco-initiatives. From then on, some implications were suggested.
\end{abstract} companies; Vietnam 


\section{INTRODUCTION}

Actual existence and development of the countries in the world in the nineteenth century, twentieth and early twenty-first century show us that the economic development mainly focuses on the benefits. However, it does not include preventing problems, reducing pollution and protecting the environment. Thus, the process of economic development is bringing the world to the global issues such as poverty, environmental pollution, ecological crisis, climate change seriously. Environmental pollution is increasingly serious and direct impacts to public health. Therefore, environmental protection and sustainable development are two inseparable elements for the development of an economy - in modern society. The goal and long-term efforts of Vietnamese enterprises are to strive to build a sustainable development associated with environmental protection in the future. To achieve that goal, Vietnam enterprises should establish environmental policies to guide all employees in the company to have responsibility for the environment, comply with the law, prevent environmental pollution, maintain and improve the operation of environmental protection.

However, the implementation of policies and laws to protect the environment, and social responsibility in the business in Vietnam still has many difficulties and shortcomings due to a number of different causes. One of the main reasons is that Vietnamese enterprises do not aware correctly and fully the relationship between the business activities of their productions with environmental issues. So it is necessary to clarify this relationship in order to help change the perception of the enterprises and employees.

The relationship between the enterprises and environment is the dialectical relationship interplay. Activities of enterprises have both the positive impacts and negative impacts on the environment and vice versa. Environment also contributes to the favor or difficulty to produce. At the same time, it can be affirmed that all enterprise activities are affecting the environment. The important thing is that the enterprises recognize the necessity to minimize the negative impacts on environment by having the environmental policies. Furthermore, some studies have proved that in the enterprise, supervisory support behaviors have strong influence on employee willingness to promote eco-initiatives that will improve environmental performance to reduce natural environmental impacts. Therefore, the motivations of the research are to 
explore which environmental policies and supervisory support behaviors have the significant influences on employee willingness to promote eco-initiatives. In our conceptual model, we assumed that environmental policy and supervisory support behaviors in six areas of innovation, competence building, communication, information dissemination, rewards and recognition, management of goals and responsibilities impacted on employee willingness to promote eco-initiatives. The three-part survey which was developed from previous studies was delivered to employees in three manufacturing companies in Hà Nội and Đà Nẵng City. By using likelihood ratio tests and logistic regression analyses, the results supported both the two hypotheses. From then on, some implications were suggested.

\section{CONCEPTUAL MODEL}

In the aftermath of the 1992 United Nations Conference on Environment and Development in Rio de Janeiro, Brazil, regulations, stakeholder pressures, social desirability pressures and other external factors have forced proactive companies to adopt environmental policy and encourage supervisory support behaviors in an aim to increase employee willingness to promote eco-initiatives. Another argument of Davis (1991) and Fussler (1996) is that eco-initiatives were a means for companies to become more environmentally and economically sustainable in their activities. In environmental literature, we found no scholar assessing environmental policy and supervisory support behaviors except the study of Ramus \& Sterger (2000). Ramus \& Sterger (2000) took an initial step in developing an empirically validated relationship between employee willingness to promote eco-initiatives and work environment support dimensions. Therefore in this study, we adopt their model to build the conceptual model.

The conceptual model for the research is illustrated in the Figure 1. This figure depicts environmental policy and supervisory support behaviors as creating an impetus for environmental actions in companies, leading to environmentally proactive firms sending encouragemental signals to employees. In the conceptual model, environmental policy and employee willingness to promote eco-initiatives will have a positive relationship. Supervisory support behaviors in six areas of innovation, competence building, communication, information dissemination, rewards and recognition, management of goals and responsibilities also have positive relationship with employee willingness to promote eco-initiatives. It means that environmental 
policy and supervisory support behaviors play the role as independent variables whereas employee willingness to promote eco-initiatives is dependent variable.

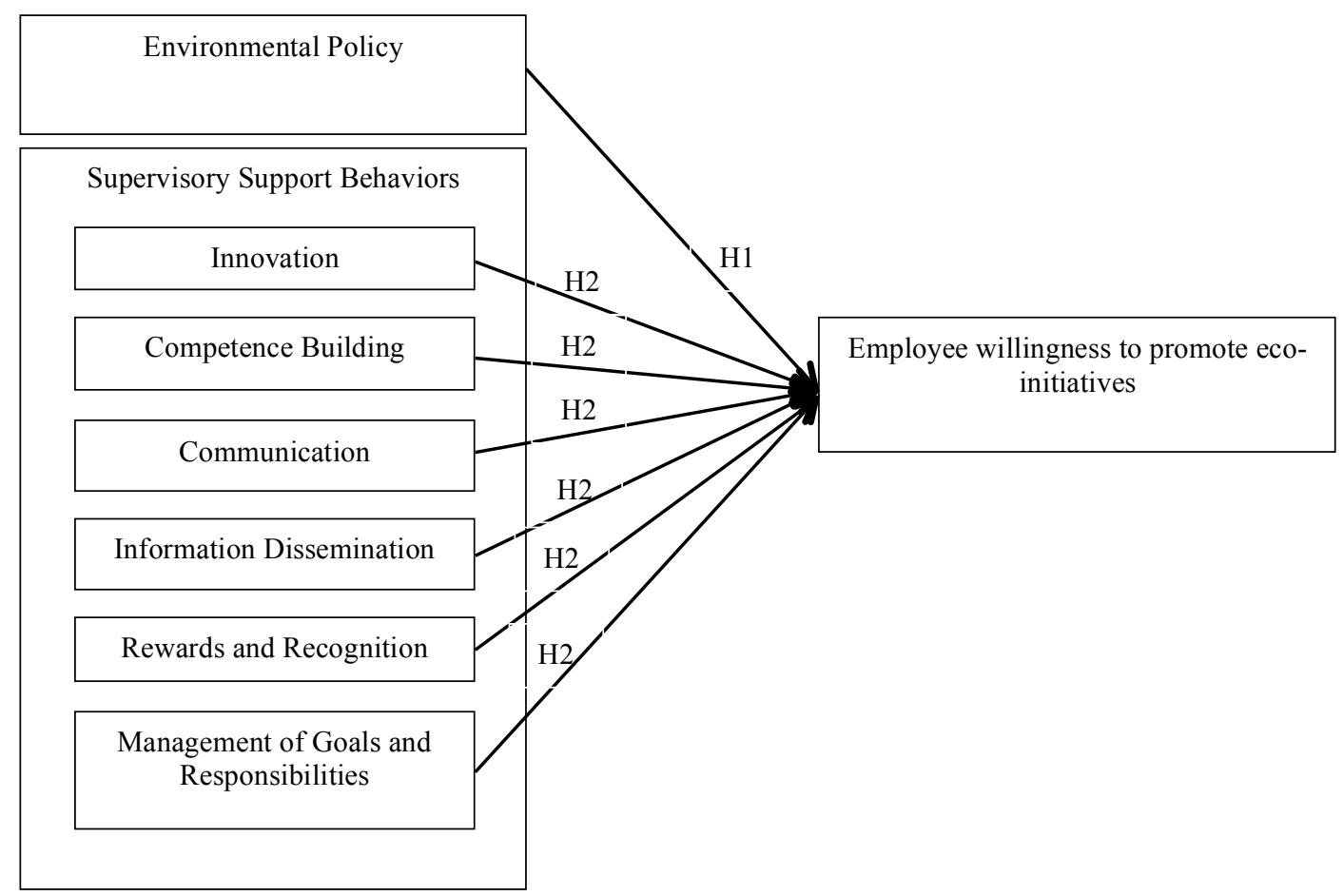

Source: adopted from the study of Ramus \& Sterger (2000)

\section{a. Environmental Policy:}

The cause-effect relationship between environmental policy and employee engagement in environmental activities has shown in a number of studies (Barret \& Murphy, 1996; Brophy, 1996; Hutchinson, 1996). Ramus \& Sterger (2000) used environmental policy as the proxy for organizational encouragement to test whether, if employees perceived a strong signal from an organizational policy, the perceptions of organizational commitment positively affected their willingness to promote ecoinitiatives. Therefore, the hypothesis 1 was proposed:

Hypothesis 1: Environmental policies will influence on employee willingness to promote eco-initiatives.

\section{b. Supervisory Support Behaviors:}


Researchers have clearly recognized the role of supervisory support behaviors in employees' willingness to promote eco-initiatives (Davis, 1991; Fussler, 1996; Ramus \& Sterger, 2000). Especially, based on previous studies, Campbell \& Cairns (1994) and Ramus \& Sterger (2000) identified the relationship between supervisory support behaviors and employee willingness to promote self-described environmental initiatives in six important areas of innovation, competence building, communication, information dissemination, rewards and recognition, measurable goals and responsibilities.

In the area of innovation, Campbell \& Cairns (1994) and Ramus \& Sterger (2000) discussed the importance of values of supervisory support behaviors to the rate of innovation in organizations. Regarding supervisory support behaviors for innovation, many studies examined the positive effects on creation of new ideas and promotion of innovation within a company (Cummings, 1965; Delbecq \& Mills, 1985; Ettlie, 1983; Hage \& Dewar, 1973; Kanter, 1983; Kimberley \& Evanisko, 1981).

In the area of competence building, Campbell \& Cairns (1994) and Ramus \& Sterger (2000) demonstrated the positive influences of supervisory support behaviors on employee education. The significant effects of employees' training on their participation in environmental activities also highlighted by Langley \& Jones (1988); Wehrmeyer, 1996) and Wehrmeyer (1996).

In the area of communication, the issue of nonhierarchical, flexible structures in encouraging employee empowerment and creativity was discussed by Campbell \& Cairns (1994) and Ramus \& Sterger (2000). The support of supervisory to share the ideas of employees in the organization was also concerned by Bowen \& Lawler (1992), Kanter (1983), Kimberley \& Evanisko (1981) and Speitzer (1995).

In the area of information dissemination, information was described as the foundation to illustrate the trust and connection between supervisory and employee in the company (Campbell \& Cairns, 1994; Ramus \& Sterger, 2000). Supervisory support behaviors including the open sharing of information about both company policies and goals and difficult subjects like layoffs and restructurings were also examined by Bowen \& Lawler (1992) and Speitzer (1995).

In the area of rewards and recognition, Campbell \& Cairns (1994) and Ramus \& Sterger (2000) demonstrated supervisory support behaviors that reinforced employee participation through formal awards, monetary rewards, and informal recognition of 
employee activities. The positive influence of rewards and recognition of supervisory on employee was also indicated in researches of Bowen \& Lawler (1992) and Lawler $(1973,1990)$.

In the area of goals and responsibilities, Campbell \& Cairns (1994) and Ramus \& Sterger (2000) proved that setting measurable and clear goals could positively affect organizational learning and employee creativity. The idea of goal clarity and sharing of responsibility for organizational goals to employee self-described environmental initiatives was also concerned by many researchers (Abbey \& Dickson, 1983; Andrews, 1975; Ellison, James, McDonald, Fox, \& Taylor, 1968; Pelz, 1956; Taylor, 1963; Witt \& Beorkrem, 1989).

From all of the above arguments, the hypothesis 2 was proposed:

Hypothesis 2a: Supervisory support behaviors that encourage employees' innovation will influence on employee willingness to promote eco-initiatives.

Hypothesis 2b: Supervisory support behaviors that encourage employees' competence building will influence on employee willingness to promote ecoinitiatives.

Hypothesis 2c: Supervisory support behaviors that encourage employees' communication will influence on employee willingness to promote eco-initiatives.

Hypothesis 2d: Supervisory support behaviors that encourage employees' information dissemination will influence on employee willingness to promote ecoinitiatives.

Hypothesis 2e: Supervisory support behaviors that encourage employees using rewards and recognition will influence on employee willingness to promote ecoinitiatives.

Hypothesis 2f: Supervisory support behaviors that encourage employees by managing goals and responsibilities will influence on employee willingness to promote eco-initiatives.

\section{METHODS}

\section{a. Sample and Procedures:}

The sample was composed of 212 mid- and low- level employees. These employees worked at three companies located in Hà Nội and Đà Nẵng City in Vietnam, each of which represented for majority of market share in their city. These manufacturing 
companies belong to construction products, including steel, sanitary ware and ceramic. We chose these companies based on their proactive environmental management programs indicated by their environmental awards from authorized organization. Moreover, we chose randomly employees from diverse workforce unites accounting for different functions and divisions. We are not interested in cross-company comparisons, but rather, in testing our hypotheses by obtaining a diverse sample of employees working in different companies.

Data was collected from questionnaire survey during January 2013. As mentioned above, the respondents are mid- and low- level employees. They returned the questionnaires directly to us for processing, and only aggregate results were reported back to those companies. We distributed 300 questionnaires and collected 212, thus the response rate was $71 \%$ percent.

\section{b. Questionnaire and Measures:}

Questionnaire was designed in three parts based on previous studies (Cooper \& Emory, 1991; Ramus \& Sterger, 2000; Remenyi, Williams, Money \& Swart, 1998). The first part including 13 questions asked about employees' perception of environmental policies. The first policy question was designed in an aim to know whether the company of the employ published environment policies or not whereas other 12 questions concerned about the issues involving environment policies of the company (see Table 1). All 13 questions were measured following a five point scale ( $2=$ strongly agree, $1=$ partially agree, $0=$ do not know, $-1=$ partially disagree, $-2=$ strongly disagree)

Table 1: Environmental Policy Questions

\section{Item Question}

$1 \quad$ Publishes an environmental policy.

2 Has specific targets for environmental performance.

3 Publishes an annual environmental report.

4 Uses an environmental management system.

5 Applies environmental considerations to purchasing decisions. 
$6 \quad$ Provides employee environmental training.

$7 \quad$ Makes employees responsible for company environmental performance.

$8 \quad$ Uses life cycle analysis.

9 Has management which understands/addresses issue of sustainable development.

10 Systematically reduces fossil fuel use.

11 Systematically reduces toxic chemicals use.

12 Systematically reduces consumption of unsustainable products.

13 Applies the same environmental standards at home and abroad.

The second part of the survey was designed by developing from questionnaires of Hampton, Summer \& Webber (1987) and Landy \& Farr (1983) to ask about supervisory environmental support behaviors in six areas of innovation, competence building, communication, information dissemination, rewards and recognition, management of goals and responsibilities(see Table 2). As was done in the first part, all questions in the second part were also measured following a five-point scale $(2=$ strongly agree, $1=$ partially agree, $0=$ do not know, $-1=$ partially disagree, $-2=$ strongly disagree).

Table 2: Supervisory Support Behaviors in Six Areas

\section{Questions regarding innovation}

\section{My supervisor:}

1

Usually objects to changes and new ideas and finds excuses why they cannot be implemented.

2 Seldom experiments with new ideas or methods of doing things.

3 I would never approach my manager with a suggested change because I know s/he would be angry with me for interfering in his/her area of responsibility.

$4 \quad$ Neither encourages nor discourages new ideas from employees.

5 Gives feedback to employees on their ideas and suggestions, even if they are not adopted.

6 Would accompany an employee to discuss and promote the employee's idea to another manager. 
Experiments with new ideas in order to examine whether they are profitable/feasible to adopt on a large scale.

When someone makes a mistake, we usually discuss, as a group, how to avoid the problem in the future.

9

Sends employees to other locations in the company and elsewhere to learn about innovative processes and other ways of doing business.

10 Encourages partnerships with other departments in order to implement new ideas.

\section{Questions regarding competence building}

My supervisor:

1 Refuses to commit resources and employee time for training and education activities.

2

Delays giving employees the training/education they need when they change their job functions.

3 Neither encourages nor discourages employee participation in training and education.

4

Usually encourages participation in any appropriate learning situation in which an employee would like to engage.

5

If there is something new I need to know, my manager will make sure I have training/education on it quickly.

6

Realigns employee responsibilities to allow employee time for training, site visits, or exploring new techniques for doing his/her job.

7 Spends time discussing and implementing a learning plan with each employee.

\section{Questions regarding communication}

My supervisor:

Reinforces organizational hierarchies by insisting that employees be of the same level or

1 the level immediately above in order to communicate (i.e., does not want employees to talk to other managers).

2 Avoids difficult discussions and ignores problems as they are developing.

3 Listens to employees, then forgets/ignores what they have said.

$4 \quad$ Neither encourages nor discourages employee communication.

5 Encourages employees to express concerns about company decisions and policies so that the concerns can be openly discussed. 
Creates an open environment in which to discuss decisions which affect the business. For

6 example, welcomes employee discussions about possible changes, improvements or problems that need solving.

7 Answers questions honestly even if the answer is not what the employee wants to hear.

8 Listens to and values input from employees and managers from all parts of the company.

9 Listens openly and attentively to suggested improvements in how s/he does his/her job and often adopts the suggestions.

\section{Questions regarding information dissemination}

My supervisor:

1 Our group is often the last to know about changes in the company because our manager does not tell us things.

2 Tries to hide unpopular decisions and information from employees.

3 Gives incomplete or inaccurate information to employees.

4

Keeps information about problems in our area private from the rest of the company and tries to solve them without help.

$5 \quad$ Neither actively aids nor hinders information flow to employees.

Uses information systems, such as electronic bulletin boards, videos, computer systems, etc. to share information amongst employees.

7

If there is too much information, s/he sets priorities and establishes what is most important for employees to know.

8

Encourages employee trust by openly announcing information without delay about troubling situations, like layoffs or restructurings.

9

Clearly explains the reason for the organization's goals or policies and forewarns employees about expected changes whenever possible.

\section{Questions regarding rewards and recognition}

\section{My supervisor:}

1

I have seen my manager publicly reprimand another employee (or my manager has criticized me in front of others).

2

If I do a good job, I am not certain that my manager will notice. But, if I make a mistake, I am sure s/he will notice and probably criticize me for the mistake. 
3 Seldom, if ever, rewards or recognizes an employee for work well done.

4 Neither recognizes nor discourages employee contributions.

5 If the company does well, my manager will reward all of his/her employees.

6 Looks for opportunities to praise positive employee performance, both privately and in front of others.

7 Rewards a good idea by implementing it and giving the responsible employee(s) credit.

8 Uses company award systems to recognize particularly good performance of employees.

9 Uses bonus pay or other monetary awards to reward employees who have achieved or surpassed their goals.

\section{Questions regarding management of goals and responsibilities}

\section{My supervisor:}

1 Tries to manage every detail of an employee's work so that the employee has little freedom to do his/her job independently.

2

Seldom talks to employees about goals and responsibilities, except when required by company policies.

3 Is often vague about what $\mathrm{s} / \mathrm{he}$ wants from an employee.

$4 \quad$ Neither encourages or discourages employees from taking responsibility.

$5 \quad$ Keeps responsibility for all decisions.

6

Delegates specific tasks to employees and tells them precisely how the tasks should be performed.

7 Talks regularly with employees to assess progress toward explicit employee goals.

8 Tells an employee right away when there is something wrong with his/her work.

9 Uses both quantitative (numbers) and qualitative (quality) measures to assure individual is making progress toward or contributing to company goals.

Involves employees in changes by instilling ownership of problems and responsibilities for solutions in every employee.

The third part of the questionnaire included the question asking about whether employees had ever "tried to promote an environmental initiative within the company". The respondents just had to answer "yes or no" for this question. Actually, many 
researchers measured this question by a five point scale but this study just wanted to find out whether respondents had tried an environmental initiative or not, therefore the dependent variable in the model in logit analyses.

\section{c. Analysis Methodology:}

Because the dependent variable in this study was employee self-described environmental initiatives giving answers a choice of a yes or no response, in order to examine the hypotheses, likelihood ratio tests and logistic regression analyses were used (Cramer, 1991; Greene, 1993).

\section{RESULTS AND DISCUSSION}

Firstly, hypothesis 1 was examined. In order to have the overall look about the environmental policy questions, means, standard deviations, and correlations of the 13 the questions were calculated (see Table 3). In general, the mean values and standard deviations showed that majority of respondents strongly agreed that their company had specific targets for environmental performance, used an environmental management system, provided employee environmental training, made employees responsible for company environmental performance, had management which understands/addresses the issue of sustainable development, systematically reduced toxic chemicals use. The respondents tended to agree less strongly that their company published environmental policy well and there was less agreement on publishing an annual environmental report, applying environmental considerations to purchasing decisions, using life cycle analysis, systematically reducing fossil fuel use, systematically reducing consumption of unsustainable products, applying the same environmental standards at home and abroad. Moreover, all environmental polices were correlated together. The reason was that the environmental policies were designed based on the similar foundation in an aim to support the common environmental goals of the companies. 
Table 3: Descriptive Statistics and Correlations for Environmental Policies ${ }^{\text {a }}$

\begin{tabular}{|c|c|c|c|c|c|c|c|c|c|c|c|c|c|c|c|}
\hline \multirow{2}{*}{ Variable } & \multirow{2}{*}{ Mean } & \multirow{2}{*}{$\begin{array}{l}\text { Standard } \\
\text { deviation }\end{array}$} & \multicolumn{13}{|c|}{ Correlation } \\
\hline & & & 1 & 2 & 3 & 4 & 5 & 6 & 7 & 8 & 9 & 10 & 11 & 12 & 13 \\
\hline $\begin{array}{l}\text { 1. Publishes an } \\
\text { environmental policy. }\end{array}$ & 0.90 & 1.10 & 1.00 & & & & & & & & & & & & \\
\hline $\begin{array}{l}\text { 2. Has specific targets } \\
\text { for environmental } \\
\text { performance. }\end{array}$ & 1.33 & 0.79 & 0.51 & 1.00 & & & & & & & & & & & \\
\hline $\begin{array}{l}\text { 3. Publishes an } \\
\text { annual environmental } \\
\text { report. }\end{array}$ & 1.06 & 0.96 & 0.56 & 0.56 & 1.00 & & & & & & & & & & \\
\hline $\begin{array}{l}\text { 4. Uses an } \\
\text { environmental } \\
\text { management system. }\end{array}$ & 1.22 & 0.96 & 0.46 & 0.66 & 0.59 & 1.00 & & & & & & & & & \\
\hline $\begin{array}{l}\text { 5. Applies } \\
\text { environmental } \\
\text { considerations to } \\
\text { purchasing decisions. }\end{array}$ & 1.08 & 0.88 & 0.43 & 0.44 & 0.47 & 0.52 & 1.00 & & & & & & & & \\
\hline $\begin{array}{l}\text { 6. Provides employee } \\
\text { environmental } \\
\text { training. }\end{array}$ & 1.37 & 0.86 & 0.38 & 0.48 & 0.47 & 0.50 & 0.43 & 1.00 & & & & & & & \\
\hline $\begin{array}{l}\text { 7. Makes employees } \\
\text { responsible for } \\
\text { company } \\
\text { environmental } \\
\text { performance. }\end{array}$ & 1.44 & 0.76 & 0.26 & 0.42 & 0.32 & 0.45 & 0.5 & 0.69 & 1.00 & & & & & & \\
\hline $\begin{array}{l}\text { 8. Uses life cycle } \\
\text { analysis. }\end{array}$ & 1.03 & 0.91 & 0.47 & 0.48 & 0.46 & 0.62 & 0.64 & 0.44 & 0.43 & 1.00 & & & & & \\
\hline $\begin{array}{l}\text { 9. Has management } \\
\text { which } \\
\text { understands/addresses } \\
\text { issue of sustainable } \\
\text { development. }\end{array}$ & 1.22 & 0.84 & 0.36 & 0.41 & 0.43 & 0.42 & 0.52 & 0.45 & 0.48 & 0.56 & 1.00 & & & & \\
\hline $\begin{array}{l}\text { 10. Systematically } \\
\text { reduces fossil fuel } \\
\text { use. }\end{array}$ & 0.87 & 1.00 & 0.44 & 0.40 & 0.42 & 0.29 & 0.49 & 0.36 & 0.35 & 0.58 & 0.51 & 1.00 & & & \\
\hline $\begin{array}{l}\text { 11. Systematically } \\
\text { reduces toxic } \\
\text { chemicals use. }\end{array}$ & 1.31 & 0.94 & 0.35 & 0.50 & 0.45 & 0.50 & 0.43 & 0.55 & 0.50 & 0.59 & 0.44 & 0.52 & 1.00 & & \\
\hline $\begin{array}{l}\text { 12. Systematically } \\
\text { reduces consumption }\end{array}$ & 1.09 & 1.01 & 0.30 & 0.39 & 0.42 & 0.36 & 0.47 & 0.45 & 0.46 & 0.41 & 0.46 & 0.56 & 0.60 & 1.00 & \\
\hline
\end{tabular}


of unsustainable

products.

13. Applies the same

environmental

standards at home

and abroad.

${ }^{\mathrm{a}}$ All correlations are significant at $\mathrm{p} \leq 0.01$

After checking means, standard deviation and correlations of 13 environmental policies, a likelihood ratio test and logit analyses were carried out to examine the cause-effect relationships between employee self-described environmental initiatives and 13 environmental policies. Firstly, the likelihood ratio test of significance showed that the environmental policies influences on employee willingness to promote ecoinitiatives $(p=0.00)$. However, the likelihood ratio test could indicate the significant influences from the environmental policies on employee willingness to promote ecoinitiatives but showed exactly which policies were impacted. Thus binary logistic regressions were performed for individual policy.

Table 4 showed the results of binary logistic regressions for environmental policies. It could be clearly seen that all 13 environmental policies had significant influences on employee willingness to promote eco-initiatives. Moreover, the strengths of coefficients illustrated the strong impacts of environmental policies. Policies that provided employees environmental training had the strongest impact with the coefficient of 1.6 , following by polices made employee environmental training, applied environmental considerations to purchasing decisions and systematically reduced fossil fuel use.

It seemed that all environmental policies that had empirical and directly impacts on employees would had more strong influences on the awareness of employees about coinitiatives. The smallest strength coefficient came from publishing an environmental policy, followed by policies used an environmental management system. Two kinds of environmental policies were just focused on announcing policies but did not make employees understand the necessity of why the company needed to apply them. 
Table 4: Results of Binary Logistic Regressions for Environmental Policies ${ }^{\text {a }}$

\begin{tabular}{|c|c|c|c|c|c|}
\hline Policy & Constant & $\mathbf{p}$ & Variable & Coefficient & $\mathbf{p}$ \\
\hline 1 & -0.76 & $0.00 *$ & Publishes an environmental policy. & 0.46 & $0.00^{*}$ \\
\hline 2 & -1.30 & $0.00 *$ & $\begin{array}{l}\text { Has specific targets for environmental } \\
\text { performance }\end{array}$ & 0.70 & $0.00^{*}$ \\
\hline 3 & -1.25 & $0.00 *$ & Publishes an annual environmental report. & 0.81 & $0.00 *$ \\
\hline 4 & -0.92 & $0.00^{*}$ & Uses an environmental management system. & 0.47 & $0.00 *$ \\
\hline 5 & -1.76 & $0.00^{*}$ & $\begin{array}{l}\text { Applies environmental considerations to } \\
\text { purchasing decisions. }\end{array}$ & 1.22 & $0.00 *$ \\
\hline 6 & -2.77 & $0.00 *$ & Provides employee environmental training. & 1.6 & $0.00 *$ \\
\hline 7 & -2.44 & $0.00^{*}$ & $\begin{array}{l}\text { Makes employees responsible for company } \\
\text { environmental performance. }\end{array}$ & 1.37 & $0.00^{*}$ \\
\hline 8 & -1.16 & $0.00^{*}$ & Uses life cycle analysis. & 0.77 & $0.00 *$ \\
\hline 9 & -1.52 & $0.00^{*}$ & $\begin{array}{l}\text { Has management which understands/addresses } \\
\text { issue of sustainable development. }\end{array}$ & 0.92 & $0.00 *$ \\
\hline 10 & -1.38 & $0.00 *$ & Systematically reduces fossil fuel use. & 1.09 & $0.00 *$ \\
\hline 11 & -1.30 & $0.00^{*}$ & Systematically reduces toxic chemicals use. & 0.70 & $0.00^{*}$ \\
\hline 12 & -1.45 & $0.00 *$ & $\begin{array}{l}\text { Systematically reduces consumption of } \\
\text { unsustainable products. }\end{array}$ & 0.93 & $0.00 *$ \\
\hline 13 & -1.06 & $0.00^{*}$ & $\begin{array}{l}\text { Applies the same environmental standards at } \\
\text { home and abroad. }\end{array}$ & 0.71 & $0.00 *$ \\
\hline
\end{tabular}

${ }^{\mathrm{a}}$ The dependent variable was employee willingness to promote eco-initiatives $* \mathrm{p} \leq 0.01$

Hypothesis 2a-2f tested the probability that employees who received supervisory support behaviors in six areas of innovation, competence building, communication, information dissemination, rewards and recognition, management of goals and responsibilities which would be likely to try to promote eco-initiatives. Table 5 showed the descriptive statistics and correlations for supervisory support behaviors. The mean and standard deviation values illustrated that the answers tended to strongly agree that their company had done innovation, management of goals and responsibilities, and competence building well. Communication, rewards and recognition, and especially information dissemination were evaluated with less agreement. Moreover, six areas 
were found to have significant correlations with each other. This could be explained that management behaviors might be related to on another.

Table 5: Descriptive Statistics and Correlations for Supervisory Support Behaviors in Six Areas ${ }^{a}$

\begin{tabular}{|c|c|c|c|c|c|c|c|c|}
\hline \multirow{2}{*}{ Variable } & \multirow{2}{*}{ Mean } & \multirow{2}{*}{$\begin{array}{l}\text { Standard } \\
\text { deviation }\end{array}$} & \multicolumn{6}{|c|}{ Correlation } \\
\hline & & & 1 & 2 & 3 & 4 & 5 & 6 \\
\hline 1. Innovation & 1.24 & 0.79 & 1.00 & & & & & \\
\hline 2. Competence building & 1.11 & 0.93 & 0.75 & 1.00 & & & & \\
\hline 3. Communication & 1.09 & 0.87 & 0.67 & 0.81 & 1.00 & & & \\
\hline $\begin{array}{l}\text { 4. Information } \\
\text { dissemination }\end{array}$ & 0.77 & 0.84 & 0.45 & 0.56 & 0.60 & 1.00 & & \\
\hline $\begin{array}{l}\text { 5. Rewards and } \\
\text { recognition }\end{array}$ & 1.08 & 0.97 & 0.69 & 0.74 & 0.69 & 0.50 & 1.00 & \\
\hline $\begin{array}{l}\text { 6. Management of goals } \\
\text { and responsibilities }\end{array}$ & 1.17 & 0.87 & 0.74 & 0.78 & 0.79 & 0.52 & 0.76 & 1.00 \\
\hline
\end{tabular}

${ }^{\mathrm{a}}$ All correlations are significant at $\mathrm{p} \leq 0.01$

By taking same steps to check the hypothesis 1, firstly a likelihood ratio test was applied. Taken together, six environmental behavior variables had a strong influence on eco-initiatives. In the next step, binary logistic regressions were performed taking each of the 6 independent variables one at a time in order to avoid multi-collinearity. Results of binary logistic regressions for supervisory support behaviors in six areas of innovation, competence building, communication, information dissemination, rewards and recognition, management of goals and responsibilities with employee willingness to promote eco-initiative as dependent variable were showed in Table 6.

As can be seen in Table 6, five out of six binary logistic regressions were significant, except information dissemination. The explanation was that pressures form information coming from outside an organization might affect employee behaviors more strongly (Ramus \& Sterger, 2000; Steger, 1998). Among five significant binary logistic regressions, innovation had the highest coefficient, following by rewards and recognition. It was not surprising because innovation would help employee to have more motivations to promote eco-initiatives whereas rewards and recognition might encourage employees to keep promoting. Thus, if the company wants their employees 
to promote eco-initiatives, the fastest way is increasing environmental innovation and having good rewards and recognition. Communication was the least variable that had influence on employee environmental eco-initiatives. The reason might come from the hierarchical systems in Vietnamese mind, therefore even though employees can discuss their opinions with managers; employees still kept some distances and respected the ideas of their seniors.

Table 6: Results of Binary Logistic Regressions for Supervisory Support Behaviors in Six Areas ${ }^{a}$

\begin{tabular}{ccclcc}
\hline Policy & Constant & $\mathbf{p}$ & \multicolumn{1}{c}{ Variable } & Coefficient & $\mathbf{p}$ \\
\hline 1 & -2.71 & $0.00^{*}$ & Innovation & 1.74 & $0.00^{*}$ \\
2 & -2.18 & $0.00^{*}$ & Competence building & 1.47 & $0.00^{*}$ \\
3 & -1.52 & $0.00^{*}$ & Communication & 1.01 & $0.00^{*}$ \\
4 & -0.50 & $0.01^{*}$ & Information dissemination & 0.22 & 0.19 \\
5 & -2.40 & $0.00^{*}$ & Rewards and recognition & 1.64 & $0.00^{*}$ \\
6 & -2.04 & $0.00^{*}$ & Management of goals and & 1.32 & $0.00^{*}$ \\
& & & responsibilities & & \\
\hline
\end{tabular}

${ }^{\text {a }}$ The dependent variable was employee willingness to promote eco-initiatives $* \mathrm{p} \leq 0.01$

\section{IMPLICATIONS}

\section{a. Implications for Vietnamese Enterprises:}

The research was showing the relationship between employee willingness to promote self-described environmental initiatives and their perceptions of factors of environmental policies and supervisory encouragement in companies. The living standard of consumers is becoming higher and higher, therefore consumers want not only good products but also friendly-environmental products. Thus if Vietnamese enterprises want to exist and develop sustainably, they should focus more on ecoinitiatives. From the results of the research, some implications were suggested as follows: 
Firstly, Vietnamese enterprises should pay more attentions to environmental policies. From the clear perception of the relationship between business activities and the environment, the business should be uniformly applied following three solutions:

- Group cognitive measures of business: Enterprises need to change the perception of the general environmental protection and environmental protection in the commercial sector in particular, especially applying cleaner technology solutions. The goal of cleaner production is to avoid pollution due to using natural resources, raw materials and energy. This means that instead of being disposed, a material proportion of the money is transferred into the finished product. To achieve this target, Vietnamese enterprises can use cleaner production. For the production process, cleaner production includes conserving materials and energy, eliminating toxic raw materials, reducing the amount and toxicity of all emissions of waste at source. For products, cleaner production involves reducing the negative impact throughout the product life cycle, from design to disposal. For services, cleaner production brings environmental factors in design and development services. The solution of cleaner production can be:

Avoiding leakage, spillage during transportation and manufacturing, also known as a local control;

Ensuring optimal production conditions from the point of product quality, production, resource consumption and waste generated;

Avoiding the use of toxic materials by using alternative materials;

Improving equipment to promote production processes;

Installing an effective manufacturing, and product design in order to minimize the consumption of resources.

- Solutions to improve the financial capability of the enterprises for the purpose of developing its activities without adversely affecting the environment in addition to investment funding for environmental protection: Environmental protection is not contrary to the natural reduction in business profits or increase production costs. The two fields are not always antagonistic, but sometimes also support each other. In developed countries, with products of environmental certification ISO 14000, although possibly higher priced products of the same type, the people still prefer to use such products because of their high consciousness for protecting the environment. 
- Solutions to improve the environmental management system in enterprises: Vietnamese enterprises should have plans to train human resources expertise about environmental regulations. Vietnamese enterprises may build a team to specialize in environment, avoiding to overlapping among departments. The members in the team need to have the good knowledge about the enterprises, laws and environment. Besides, the members also know how to operate and control environmental systems following the standards, plan and report frequently all environmental issues. The team will announce and explain clearly the environmental polices for every employee in the enterprises. Moreover, the team can organize the environmental training courses for all employees in the enterprise to raise the environmental awareness or guide employees how to be responsible for company environmental performance.

Secondly, supervisory behaviors need to be reviewed to increase employee willingness to promote eco-initiatives. The results of the research showed that supervisory support behaviors encouraging environmental innovation, competence building, communication, rewards and recognition, and management goals and responsibilities had a statistically significant influence on employee willingness to promote eco-initiatives. The research also proved that innovation as well as rewards and recognition spilled over strongly; therefore supervisor should focus on two factors. For innovation, supervisors should experiment with new ideas or methods or encourage and discuss new ideas from employees to promote eco-initiatives. For rewards and recognition, managers should look for opportunities to praise positive employee performance both privately and in front of others or use bonus pay or other monetary awards to rewards employees who have achieved or surpassed their goals. Competence building as well as management of goals and responsibilities also need to be paid more attention by delegating specific tasks to employees and tell them precisely how the task should be performed and support them to do it with spending time discussing and implementing a learning plan. In regard with communication, if supervisors want to increase the effectiveness, supervisors should encourage employees more to express concerns about company decisions and policies, create an open environment and answer questions honestly.

\section{b. Implications for the Government:}

In Vietnam, the government is responsible for supporting, with appropriate policy mechanisms to capital for businesses; resolute sanctions enforcement existing law 
while continuing to improve the legal basis. According to the experience of the advanced countries, the application of environmental management measures integrated solution consists of three groups: legal instruments, economic instruments, and communications tools. That is a synchronous system with policies, legislation, remedies that are very effective in controlling and reducing environmental pollution such as air, noise and water especially. Once the law was strict, mandatory remediation, strict sanctions for violations, the enterprises will know how to find ways to reduce waste, such as separating stormwater from wastewater stream, improving manufacturing processes, increasing the use of the raw material, recycling products quality not to reduce waste.

In recent years, Vietnam has been invested to promote and implement cleaner technologies. The principle here does not primarily concern only handling waste, which is to reduce waste through reusing, recycling, and waste prevention. Vietnamese enterprises need to promote adoption of cleaner technologies; particularly in the small and medium enterprises have little access to knowledge and technology needed. The government also needs to support the enterprises as they actually contribute significantly to job creation and GDP growth for the country

\section{References}

Abbey, A. \& J. W. Dickson, (1983), "R\&D Climate and Innovation in Semiconductors", Academy of Management Journal, 26: 362-368.

Andrews, F. M. (1975), "Social and Psychological Factors that Influence the Creative Process" in A. T. J.W. Getzels (Ed.), Perspective in Creativity, 117-145, Chicago: Aldine.

Barret, S. \& D. Murphy (1996), "Managing Corporate Environmental Policy: A Process of Complex Change" in W. Wehrmeyer (Ed.), Green People, 75-98, Sheffield, Englang: Greenleaf.

Bowen, D. E. \& E. E. Lawler (1992), "The Empowerment of Service Workers: What, Why, How and When" Sloan Management Review, 33(3): 31-39.

Brophy, M. (1996), "The Essential Characteristics of an Environmental Policy" in R. Welford (Ed.), Corporate Environmental Management: Systems and Strategies, 92-103, London: Earthscan.

Campbell, T. \& H. Cairns (1994), "Developing and Measuring the Learning Organization: From Buzz Words to Behaviors", Industrial and Commercial Training, 26(7): 10-15.

Cooper, D. R. \& W. C. Emory, (1991), "Business Research Methods", Chicago: Irwin.

Cramer, J. S. (1991), The Logit Model. New York: Chapman and Hall. 
Cummings, L. L. (1965), "Organizational Climates for Creativity", Journal of the Academy of Management, 3: 220-227.

Davis, J. (1991), Greening Business: Managing for Sustainable Development, Oxford: Basil Blackwell.

Delbecq, A. L. \& P. K. Mills (1985), "Managerial Practices that Enhance Innovation", Organizational Dynamics, 14(1): 24-34.

Ellison, R. L., L. R. James, B. W., D. G. Fox \& C. W. Taylor (1968), "Goals: An Approach to Motivation and Achievement", Journal of Personality and Social Psychology, 54: 5-12.

Ettlie, J. E. (1983), "Organizational Policy and Innovation among Suppliers to the Food Processing Sector", Academy of Management Journal, 26: 27-44.

Fussler, C. (1996), Driving Eco-Innovation: A Break-Through Discipline for Innovation and Sustainability, London: Pitman.

Greene, W. H. (1993), Econometric Analysis (2nd ed.), Englewood Cliffs, NJ:: Prentice-Hall.

Hage, J. \& R. Dewar (1973), "Elite Values Versus Organizational Structure in Predicting Innovation", Administrative Science 18: 279-290.

Hampton, D. R., C. E. Summer \& R. A. Webber (1987), Organizational Behavior and the Practice of Management (5th ed.), Glenview, IL: Foresman \& Co.

Hutchinson, C. (1996), "Corporate Strategy and the Environment", in R. W. R. Starkey (Ed.), Business and the Environment (pp. 85-104), London: Earthscan.

Kanter, R. M. (1983), The change masters. New York: Simon \& Schuster.

Kimberley, J. R. \& M. J. Evanisko (1981), "Organizational Innovation: The Influence of Individual, Organizational, and Contextual Factors on Hospital Adoption of Technological and Administrative Innovations", Academy of Management Journal, 24: 687-713.

Landy, F. \& J. Farr (1983), The Measurement of Work Performance: Method, Theory \& Applications, New York: Academic Press.

Langley, P. \& R. Jones (1988), "A Computational Model of Scientific Insight" in R. J. Sternberg (Ed.), The Nature of Creativity (pp. 177-201), New York: Cambridge University Press.

Lawler, E. E. (1973), Motivation in Work Organizations, Pacific Grove, CA: Brooks and Cole.

Lawler, E. E. (1990), Strategic Pay: Aligning Organizational Strategies and Pay Systems, San Francisco: Jossey-Bass.

Pelz, D. C. (1956), "Some Social Factors Related to Performance in Research Organizations", Administrative Science Quarterly, 1: 310-325.

Ramus, C. A. \& U. Sterger (2000), "The Roles of Supervisory Support Behaviors and Environmental Policy in Employee 'Ecoinitiatives' at Leading-Edge European Companies", Academy of Management Journal, 43(4): 605-626. 
Remenyi, D., B. Williams, A. Money \& E. Swart (1998), Doing Research in Business and Management, London: Sage.

Speitzer, G. M. (1995), "Psychological Empowerment in the Workplace: Dimensions, Measurement, and Validation", Academy of Management Journal, 38: 1442-1465.

Steger, U. (1998), The Strategic Dimensions of Environmental Management: Sustaining the Corporation During the Age of Ecological Discovery, London: Macmillan.

Taylor, C. W. (1963), "Variables Related to Creativity and Productivity among Men in Two Research Laboratories" in C. W. T. R. Baron (Ed.), Scientific Creativity: Its Recognition and Development, (pp. 225-271), New York: Wiley.

Vietnamese Ministry of Industry and Trade (2006), Report of Vietnamese E-Commerce.

Wehrmeyer, W. (1996), Greening People, Sheffield, England: Greenleaf.

Witt, L. A. \& M. N. Beorkrem (1989), "Climate for Creative Productivity as a Predictor of Research Usefulness and Organizational Effectiveness in R\&D Organizations", Creativity Research Journal, 2: 30-46. 